\title{
Effect of Moringa oleifera Supplementation on Oxidative Stress Biomarkers during Infectious Bursal Disease Virus Infection in Broiler Chickens
}

\author{
${ }^{1 *}$ Balami, A. G., ${ }^{2}$ Sule, A. G., ${ }^{3}$ Enam, S. J., ${ }^{4}$ Gadzama, J. J., ${ }^{5}$ Ndahi, J. J., ${ }^{1}$ Mustapha, M., \\ ${ }^{1}$ Lawan, A., ${ }^{6}$ Wakawa. A. M., ${ }^{7}$ Aluwong, T. and ${ }^{4}$ Abdu, P. A.
}

${ }^{1}$ Department of Veterinary Medicine, University of Maiduguri, ${ }^{2}$ Department of Veterinary Public Health and Preventive Medicine, University of Maiduguri, ${ }^{3}$ Department of Veterinary Pathology, Ahmadu Bello University, Zaria, ${ }^{4}$ Department of Veterinary Pathology, University of Maiduguri, ${ }^{5}$ Department of Veterinary Microbiology, University of Maiduguri, ${ }^{6}$ Department of Veterinary Medicine, Ahmadu Bello University, Zaria, ${ }^{7}$ Department of Veterinary Physiology, Ahmadu Bello University, Zaria

*Author for Correspondence: talktoarrow@yahoo.com

\begin{abstract}
This study was designed to assess the effect of Infectious Bursal Disease Virus (IBDV) on oxidative stress biomarkers in broiler chickens fed Moringa oleifera leaf (MOL)supplemented feed. Two hundred- and forty-day-old Ross 308 hybrid broiler chicks were randomly assigned into groups $\mathrm{A}, \mathrm{B}, \mathrm{C}$ and $\mathrm{D}$ of 60 chicks each. The chicks were raised on deep litter housing. Broiler starter (BS) and broiler finisher (BF) mash were formulated for broilers in groups A and B each with 5\% MOL supplemented as part of the feed. while BS and BF were formulated without MOL for broilers in groups $\mathrm{C}$ and D. Broiler chickens in groups $\mathrm{A}, \mathrm{B}$ and $\mathrm{C}$ were challenged with $0.05 \mathrm{ml}$ of a live vvIBDV at 35 days of age, whereas those in group D served as controls. At days 35, 38, 42 and 49 of age, blood was collected from 10 broilers in each group via the wing vein to determine serum concentration of Catalase (CAT), Glutathione peroxidase (GPx), Superoxidase dismutase (SOD) and Malondialdehyde (MDA) using an Audio comb Serum Auto-analyser. There was a significant increase in the concentration of CAT $(\mathrm{P}=0.0125)$ and GPx $(\mathrm{P}=0.0190)$, in broilers of group A at 38 days of age when compared with the control (group D). While the concentration of MDA increased significantly in broilers of group A $(\mathrm{P}=0.0004)$ at 42 days of age when compared with the control. Moringa oleifera leaf supplementation in the feed of broilers is shown to potentiate the antioxidant activities of CAT, GPx and MDA during infection with infectious bursal disease virus.
\end{abstract}

Keywords: Chickens; Infectious bursal disease; Moringer oleifera; Oxidative stress

\section{INTRODUCTION}

Commercial poultry production has been experiencing a tremendous increase in Nigeria, thereby increasing the opportunity for the Nigerian poultry industry to strive effectively (Onu and Aniebo, 2011). Infectious diseases such as Infectious bursal diseases (IBD, also known as Gumboro disease), which is caused by an infectious bursal disease virus (IBDV), have been causing great economic loss due to mortality that ranges between $80-100 \%$ during outbreaks (Aracibasi et al., 2010; Rehman et al., 2016). Infectious bursal diseases virus causes a prolong immunosuppression that leads to increased susceptibility in the affected birds to various bacterial and viral diseases, poor immune response to other vaccines, reduced antioxidant capacity, lipid peroxidation etc, thereby rendering investment in the poultry

industry to be fearful and uncertain (Okoye, 1983; Abdu, 1986; Niki, 1996; Min et al., 2008; Aricibasi et al., 2010).
Oxidative stress occurs when there is an imbalance between free radical generation/reactive oxygen species (ROS) and antioxidant defence systems (Ames et al., 1993; Sandhu and Kaur, 2002). This free radicals/ROS cause damage to the DNA, biomembrane lipids, proteins and other macromolecules (Lu et al., 2010). Antioxidant enzymes such as superoxide dismutase (SOD), catalase (CAT) and glutathione peroxidase (GPx) are the first line defence antioxidants (Ray and Husain, 2002), while malondialdehyde (MDA) is the main oxidation product of peroxidized polyunsaturated fatty acids. The infectious bursal disease virus affects domestic chicken, thereby causing damage that is irreversible to different body tissues (Peterhens et al., 2009; Reshi et al., 2014).

Moringa oleifera (MO) is indigenous to Northwest India, but at present, it is widely distributed in the tropics, throughout the pacific region, central America, the Caribbean as well as West Africa (Ramachandran et al., 1980; Makker and 
Becker, 1999; Aregheore, 2002). Though, MO is known by most ethnic groups in Nigeria, it is commonly and widely cultivated in the Northern region of the country (Anjorin et al., 2010). The different parts of MO have for long been consumed for nutritional purpose or used as medicine (Jahn, 1984, Bukar et al., 2010). Among the several medicinal uses of MO, the antioxidant properties of Moringa oleifera leaf (MOL) has also been reported by several authors (Vyas et al., 2015; Falowo et al., 2017; Wright et al., 2017). Though, IBDV has been shown to cause oxidative stress in chickens (Ertekin et al., 2016), and the antioxidant capacity of Soya bean Isoflavones in broiler chickens during IBD infection (Azzam et al., 2019), the use of MOL supplemented diet as a source of antioxidant during IBD infection has not been reported, therefore, this study was designed to assess the effect of IBDV on oxidative stress biomarkers in broiler chickens fed MOL supplemented feed.

\section{MATERIALS AND METHODS}

\section{Study Location}

The study was carried out at the Faculty of Veterinary Medicine's Poultry Research Center, Ahmadu Bello University Samaru, Zaria, Nigeria.

\section{Ethical Statement}

The Ethics Committee of Ahmadu Bello University, Zaria, gave approval for this research and standards for the treatment and humane handling of animals were strictly adhered to during the study (FASS, 2010).

\section{Collection and Processing of Moringa oleifera Leaf}

At an early stage of blooming (between the months of August and September), the MOL was collected from an orchard. The stem and branches were cut from the Moringa trees and spread at room temperature for five days to dry out under shade. The MOL was then manually processed into powder by hand and ground using a locally made milling machine.

\section{Mineral analysis of Moringa oleifera Leaf}

Mineral analysis of MOL was carried out using the Association of Official Analytical Chemist (AOAC, 1990) technique and was found to contain calcium, phosphorus, magnesium, iron, sodium, zinc, copper, selenium, potassium and manganese (Balami et al., 2016) (Table 1).

\section{Phytochemical Analysis of Moringa oleifera Leaf}

According to the method specified by Sofowora (1993), quantitative analysis of MOL was performed and the presence of tannins, phytates, saponins, oxalates and cyanides were determined (Balami et al., 2016) (Table 2).

\section{Proximate Analysis of Moringa oleifera Leaf}

The Association of Official Analytical Chemists (AOAC, 1990) standard methods for the proximate MOL analysis was used and the estimated percentage of carbohydrates, crude protein, fats, fibre, ash, moisture, and metabolizable energy were known (Balami et al., 2016) (Table 3).

\section{Feed Formulation and Analyses}

To acquire a Moringa oleifera leaf meal, the dried MOL was milled with a hammer mill and sewn with $3 \mathrm{~mm}$ mesh sieve. Broiler starters $(22 \%$ crude protein) and broiler finishers ( $20 \%$ crude protein) were formulated on the basis of the recommended levels for broilers as stated by McDonald et al. (1995), which set protein requirements for tropical broilers at $20-22 \%$ for starters and $18-20 \%$ for finishers. Five percent MOL was included in the feed as defined using Pearson square by the Olugbemi et al. (2010) methods. Proximate and mineral analysis of the feed was carried out on the basis of the method clearly defined by the AOAC (1990) in the Feed Analysis Laboratory of the Department of Animal Science, Ahmadu Bello University, Zaria, to determine the level of metabolizable energy, moisture, ash content, dry matter, crude protein and crude fiber (Table 4).

\section{Experimental Chicks and Housing}

A total of 240-day old Ross 308 hybrid broiler chicks from a commercial hatchery located in Yola, Nigeria, were purchased. The chicks were brooded in a deep litter house. Before the arrival of the chicks, the pens were thoroughly washed and disinfected. Wood shavings used as litter material. The chicks were weighed individually and randomly distributed to contain 60 chicks each into four groups A, B, C and D. A 100-watt bulb was installed in each of the compartments to supply light and heat during brooding.

Table 1: Mineral composition of Moringa oleifera leaf

\begin{tabular}{lc}
\hline Element & Concentration \\
\hline $\mathrm{Ca}$ & $2.26 \%$ \\
$\mathrm{P}$ & $0.35 \%$ \\
$\mathrm{Mg}$ & $0.45 \%$ \\
$\mathrm{~K}$ & $1.9 \%$ \\
$\mathrm{Na}$ & $0.11 \%$ \\
$\mathrm{Zn}$ & $34 \mathrm{ppm}$ \\
$\mathrm{Cu}$ & $7.5 \mathrm{ppm}$ \\
$\mathrm{Mn}$ & $40.5 \mathrm{ppm}$ \\
$\mathrm{Fe}$ & $116.5 \mathrm{ppm}$ \\
$\mathrm{Se}$ & $0.85 \mathrm{ppm}$ \\
\hline $\mathrm{ppm}=$ parts per million $(1 \mathrm{mg} / \mathrm{kg}=1 \mathrm{ppm})$ & \\
Source; Balami et al., 2016 &
\end{tabular}


Table 2: Quantitative phytochemical composition of Moringa oleifera leaf

\begin{tabular}{lc}
\hline Phytochemical & Concentration (\%) \\
\hline Phytates & 2.57 \\
Tannins & 2.19 \\
Saponins & 1.06 \\
Oxalates & 0.45 \\
Cyanides & 0.1 \\
\hline
\end{tabular}

Source; Balami et al.,2016

Table 3: Proximate composition of Moringa oleifera leaf

\begin{tabular}{ll}
\hline Metabolite & \% composition \\
\hline Carbohydrate & 55.14 \\
Crude protein & 25.9 \\
Crude fibre & 13.91 \\
Moisture & 7.94 \\
Fat & 5.85 \\
Ash & 3.72 \\
Energy & $2930.63(\mathrm{KCal} / \mathrm{Kg})$ \\
\hline
\end{tabular}

Source; Balami et al., 2016

Table 4: Composition of experimental diets of broilers starter and finisher diets per $100 \mathrm{~kg}$ of feed

\begin{tabular}{|c|c|c|c|c|}
\hline 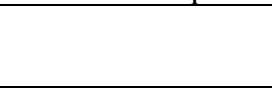 & $\begin{array}{l}\text { Broiler starter } \\
(\mathrm{A} \text { and } \mathrm{B})(\%)\end{array}$ & $\begin{array}{l}\text { Broiler finisher (A } \\
\text { and B) }(\%)\end{array}$ & $\begin{array}{l}\text { Broiler starter } \\
(\mathrm{C} \text { and } \mathrm{D})(\%)\end{array}$ & $\begin{array}{l}\text { Broiler finisher } \\
(\mathrm{C} \text { and D) }(\%)\end{array}$ \\
\hline Maize & 50.14 & 52 & 50.14 & 52 \\
\hline Maize offal & 9.2 & 10 & 9.2 & 10 \\
\hline Soybean cake & 11.69 & 8.49 & 14.19 & 10.18 \\
\hline Groundnut cake & 11.69 & 13.98 & 14.19 & 17.29 \\
\hline MOLM & 5 & 5 & 0 & 0 \\
\hline Fish meal & 5 & 5 & 5 & 5 \\
\hline Salt & 0.3 & 0.3 & 0.3 & 0.3 \\
\hline Limestone & 1.5 & 0.5 & 1.5 & 0.5 \\
\hline Bone meal & 3.5 & 3.5 & 3.5 & 3.5 \\
\hline Lysine & 0.85 & 0.5 & 0.85 & 0.5 \\
\hline Methionine & 0.85 & 0.375 & 0.85 & 0.375 \\
\hline $\operatorname{Premix}(\mathrm{B} / \mathrm{S}, \mathrm{B} / \mathrm{F})$ & 0.25 & 0.25 & 0.25 & 0.25 \\
\hline Enzyme & 0.025 & 0.1 & 0.025 & 0.1 \\
\hline Total: & 100 & 100 & 100 & 100 \\
\hline \multicolumn{5}{|l|}{ Proximate analysis } \\
\hline ME Kcal/Kg DM & 2798.45 & 2752.55 & 2687.88 & 2664.83 \\
\hline Crude protein $(\%)$ & 22.50 & 20.69 & 22.31 & 20.63 \\
\hline Crude fibre $(\%)$ & 5.53 & 5.15 & 5.06 & 5.24 \\
\hline Ether extract $(\%)$ & 16.45 & 16.69 & 16.01 & 15.93 \\
\hline
\end{tabular}

Key: MOLM: Moringa oleifera leaf meal. ME: Metabolizable energy, B/S: Broiler starter, B/F: Broiler finisher

\section{Experimental Chicks and Housing}

A total of 240-day old Ross 308 hybrid broiler chicks from a commercial hatchery located in Yola, Nigeria, were purchased. The chicks were brooded in a deep litter house. Before the arrival of the chicks, the pens were thoroughly washed and disinfected. Wood shavings used as litter material. The chicks were weighed individually and randomly distributed to contain 60 chicks each into four groups A, B, C and D. A 100-watt bulb was installed in each of the compartments to supply light and heat during brooding.

\section{Feeds and Feeding}

All the broilers were fed 28 days ( 0 to 4 weeks old) with broiler starter and 21 days broiler finisher (5 weeks to 7 weeks old). Feed was given ad libitum.

\section{Experimental Design}

Broilers in groups A and B were fed with broiler starters and finisher diets each containing $5 \% \mathrm{MOL}$, while broilers in groups $\mathrm{C}$ and $\mathrm{D}$ were fed without MOL with broiler starters and finisher feeds. Groups A, B and C were challenged with a vvIBDV when they were 35 days old. All the groups were fed for 49 days (7 weeks).

\section{Challenge with Infectious Bursal Disease Virus}

All the broilers in groups A, B and C were challenged intraocularly with $0.05 \mathrm{ml}$ of a live vvIBD virus at 35 days of age. The IBD virus used for the challenge was a vvIBDV field strain collected from previously vaccinated layers that died from natural IBD outbreaks. Sixty five percent of commercial cockerels inoculated with $50 \mu$ l bursal 
suspension (v/w) in PBS at 30 days of age (pH 7.4) died. In PBS ( $\mathrm{pH} 7.4)$ one millilitre of bursal suspension $(\mathrm{v} / \mathrm{w})$ contained $10^{-976} \mathrm{CID}_{50}$ of IBDV.

\section{Blood Sample Collection and Processing \\ Blood Sample Collection}

Blood samples were obtained for serum biochemical tests when the broilers were aged 35, 38, 42 and 49 days. Using a 25 -gauge sterile needle on a $5 \mathrm{ml}$ syringe, 10 birds from each group were selected and bled through the brachial vein on each blood collection day. Each collected blood sample was emptied into plain (without anticoagulant) test tubes, and coagulated to produce sera using the methods described by Okeudo et al. (2003). Serum was separated at $447.2 \mathrm{~g}$ for 10 min by centrifugation, and preserved at $-20^{\circ} \mathrm{C}$ before analysis. Using a permanent marker, each of the sample bottles was properly labelled.

\section{Biochemical Analyses}

The serum activity of antioxidant enzymes such as Catalase $(\mathrm{CAT})$, Glutathione peroxidase (GPx) and Superoxidase dismutase (SOD)was evaluated using commercial test kits for SOD, CAT, and GPx obtained from LLC, Vancouver, WA98662, Canada, North West Life Science and the manufacturer's instruction were fully followed in performing the test.

The level of thiobarbituric acid reactive material (TBA), malondialdehyde (MDA), as a lipid peroxidation index, was measured in the serum using Draper and Hadley's (1990) double heating method, which was revised by Yavuz et al (2004). The MDA concentration in the samples was determined using the MDA-TBA complex absorbance coefficient of $1.56 \times 105 / \mathrm{cm} / \mathrm{M}$ and reported as nmol $/ \mathrm{mg}$ protein.

\section{Statistical Analyses}

All the data were analyzed using JMP 11 software (SAS Institute Inc., Cary, NC). Analysis of variance (ANOVA) and Tukey's Kramer honest significant difference were used to compare the various groups; nominal logistic regression was used to test for changes and effects of IBDV on oxidative stress biomarkers. The data were considered significant at $\mathrm{p}<0.05$.

\section{RESULTS}

The results of the study showed a significant increase in the concentration of CAT $(\mathrm{P}=0.0125)$ (Table 5) and GPx $(\mathrm{P}=0.0190)$ (Table 6$)$, in broilers of group $\mathrm{A}$ at 38 days of age when compared with the control (group D). Also, the concentration of MDA increased significantly in broilers of group $\mathrm{A}(\mathrm{P}=0.0004)$ at 42 days of age when compared with the control (Table 7). However, no significant change was observed in the concentration of SOD in broilers of all the groups throughout the study period (Table 8).

The effect of infectious bursal disease virus on the oxidative stress biomarkers showed that MDA significantly $(\mathrm{P}=0.0006)$ increased by $0.68 \times 10^{-976}$ and GPx $(\mathrm{P}=0.0445)$ by $0.056 \times 10^{-}$ ${ }^{976}$ for every one unit increase in IBDV load in the broilers of group A at 35 days of age. Also, for every one unit increase in IBDV load, the concentration of MDA significantly $(\mathrm{P}=0.0473)$ increased by $0.36 \times 10^{-976}$ at 35 days of age and still increased significantly $(\mathrm{P}=0.0035)$ by $0.55 \times 10^{-976}$ at 38 days of age in the broilers of group B (Table 9).

Table 5: Changes in the serum concentration of Catalase $\left(\mathrm{IU}^{-1}\right)$ in broilers fed Moringa oleifera supplemented diet and inoculated with vvIBDV from 35 to 49 days of age

\begin{tabular}{ccccc}
\hline \multirow{2}{*}{$\begin{array}{c}\text { Age } \\
\text { (days) }\end{array}$} & $\begin{array}{c}\text { M. oleifera + Vaccine } \\
+ \text { Challenge } \\
(\mathbf{g})\end{array}$ & $\begin{array}{c}\text { M. oleifera + No Vaccine } \\
\text { Challenge } \\
\text { (g) }\end{array}$ & $\begin{array}{c}\text { Groups } \\
\text { Control Feed + Vaccine } \\
+ \text { Challenge } \\
\text { (g) }\end{array}$ & $\begin{array}{c}\text { Control Feed + } \\
\text { NoVaccine }+ \text { No } \\
\text { Challenge } \\
(\mathbf{g})\end{array}$ \\
\hline 35 & $52.60^{\mathrm{a}} \pm 1.01$ & $49.40^{\mathrm{a}} \pm 1.01$ & & $49.70^{\mathrm{a}} \pm 1.01$ \\
38 & $50.80^{\mathrm{a}} \pm 1.01$ & $49.70^{\mathrm{b}} \pm 1.01$ & $48.50^{\mathrm{a}} \pm 1.01$ & $46.00^{\mathrm{b}} \pm 1.01$ \\
42 & $50.30^{\mathrm{a}} \pm 1.01$ & $52.20^{\mathrm{a}} \pm 1.01$ & $48.10^{\mathrm{b}} \pm 1.01$ & $49.80^{\mathrm{a}} \pm 1.01$ \\
49 & $52.20^{\mathrm{a}} \pm 1.01$ & $50.00^{\mathrm{a}} \pm 1.01$ & $48.90^{\mathrm{a}} \pm 1.01$ & $48.80^{\mathrm{a}} \pm 1.01$ \\
\hline
\end{tabular}

All values are expressed as Means \pm SEM, values with different superscript ${ }^{\mathrm{a}, \mathrm{b}}$ within rows differ significantly at $\mathrm{p}<0.05$

Table 6: Changes in the serum concentration of Glutathione peroxidase ( $\left.\mathrm{IU}^{-1}\right)$ in broilers fed Moringa oleifera supplemented diet and inoculated with vvIBDV from 35 to 49 days of age

\begin{tabular}{ccccc}
\hline & \multicolumn{4}{c}{ Groups } \\
\cline { 2 - 5 } $\begin{array}{c}\text { Age } \\
\text { (days) }\end{array}$ & $\begin{array}{c}\text { M. oleifera + Vaccine } \\
+ \text { Challenge } \\
(\mathbf{g})\end{array}$ & $\begin{array}{c}\text { M. oleifera + No } \\
\text { Vaccine }+ \text { Challenge } \\
(\mathbf{g})\end{array}$ & $\begin{array}{c}\text { Control Feed + Vaccine } \\
+ \text { Challenge } \\
(\mathbf{g})\end{array}$ & $\begin{array}{c}\text { Control Feed + No } \\
\text { Vaccine + No Challenge } \\
(\mathbf{g})\end{array}$ \\
\hline 35 & $48.30^{\mathrm{a}} \pm 0.95$ & $46.10^{\mathrm{a}} \pm 0.95$ & $45.08^{\mathrm{a}} \pm 0.95$ & $45.80^{\mathrm{a}} \pm 0.95$ \\
38 & $47.40^{\mathrm{b}} \pm 0.95$ & $46.10^{\mathrm{a}} \pm 0.95$ & $45.08^{\mathrm{a}} \pm 0.95$ & $43.10^{\mathrm{a}} \pm 0.95$ \\
42 & $46.30^{\mathrm{a}} \pm 0.95$ & $47.60^{\mathrm{a}} \pm 0.95$ & $46.80^{\mathrm{a}} \pm 0.95$ & $46.80^{\mathrm{a}} \pm 0.95$ \\
49 & $48.20^{\mathrm{a}} \pm 0.95$ & $46.20^{\mathrm{a}} \pm 0.95$ & $46.50^{\mathrm{a}} \pm 0.95$ & $44.50^{\mathrm{a}} \pm 0.95$ \\
\hline
\end{tabular}

All values are expressed as Means \pm SEM, values with different superscript ${ }^{\mathrm{a}, \mathrm{b}}$ within rows differ significantly at $\mathrm{p}<0.05$ 
The concentration of CAT significantly $(\mathrm{P}=0.0414)$ decreased by $-0.05 \times 10^{-976}$, while MDA significantly $(\mathrm{P}=0.0001)$ increased by $0.91 \times 10^{-976}$, and GPx $(\mathrm{P}=0.0376)$ by $0.05 \times 10^{-976}$ for every one unit increase in IBDV load in the broilers of group $\mathrm{C}$ at 35 days of age. Still, the concentration of CAT significantly $(\mathrm{P}=0.0117)$ decreased by $-0.06 \times 10^{-976}$, MDA significantly $(\mathrm{P}=0.0058)$ increased by $0.52 \times 10^{-976}$ and GPx $(\mathrm{P}=0.0109)$ by $0.07 \times 10^{-976}$ with one unit increase in IBDV load in broilers of group $\mathrm{C}$ at 38 days of age. At 42 days of age, the concentration of CAT significantly $(\mathrm{P}=0.0127)$ decreased by $-0.06 \times 10^{-976}$ and GPx significantly $(\mathrm{P}=0.0019)$ increase by $0.09 \times 10^{-976}$ for every one unit increase in IBDV load in the broilers of group C. By 49 days of age, only the concentration of MDA significantly $(\mathrm{P}=0.0068)$ increased by $0.5 \times 10^{-976}$ for every one unit increase in IBDV load in the broilers of group $\mathrm{C}$ at (Table 9).

Table 7: Changes in the serum concentration of Malondialdehyde (IU $\left.{ }^{-1}\right)$ in broilers fed Moringa oleifera supplemented diet and inoculated with vvIBDV from 35 to 49 days of age

\begin{tabular}{ccccc}
\hline & \multicolumn{4}{c}{ Groups } \\
\cline { 2 - 5 } & $\begin{array}{c}\text { M. oleifera + Vaccine } \\
+ \text { Challenge } \\
(\mathbf{g})\end{array}$ & $\begin{array}{c}\text { M. oleifera + No Vaccine } \\
+ \text { Challenge } \\
(\mathbf{g})\end{array}$ & $\begin{array}{c}\text { Control Feed + Vaccine } \\
+ \text { Challenge } \\
(\mathbf{g})\end{array}$ & $\begin{array}{c}\text { Control Feed + No } \\
\text { Vaccine + No Challenge } \\
(\mathbf{g})\end{array}$ \\
\hline 35 & $1.61^{\mathrm{a}} \pm 0.09$ & $1.37^{\mathrm{a}} \pm 0.09$ & $1.76^{\mathrm{a}} \pm 0.09$ & $1.48^{\mathrm{a}} \pm 0.09$ \\
38 & $1.27^{\mathrm{a}} \pm 0.09$ & $1.51^{\mathrm{a}} \pm 0.09$ & $1.45^{\mathrm{a}} \pm 0.09$ & $1.65^{\mathrm{a}} \pm 0.09$ \\
42 & $1.34^{\mathrm{a}} \pm 0.09$ & $1.13^{\mathrm{a}} \pm 0.09$ & $1.23^{\mathrm{a}} \pm 0.09$ & $0.80^{\mathrm{a}} \pm 0.09$ \\
49 & $1.23^{\mathrm{a}} \pm 0.09$ & $1.27^{\mathrm{a}} \pm 0.09$ & $1.46^{\mathrm{a}} \pm 0.09$ & $1.13^{\mathrm{a}} \pm 0.09$ \\
\hline
\end{tabular}

All values are expressed as Means \pm SEM, values with different superscript ${ }^{\mathrm{a}, \mathrm{b}}$ within rows differ significantly at $\mathrm{p}<0.05$

Table 8: Changes in the serum concentration of Superoxidase dismutase ( $\left.\mathrm{IU}^{-1}\right)$ in broilers fed Moringa oleifera supplemented diet and inoculated with vvIBDv from 35 to 49 days of age

\begin{tabular}{|c|c|c|c|c|}
\hline \multirow[b]{2}{*}{$\begin{array}{c}\text { Age } \\
\text { (days) }\end{array}$} & \multicolumn{4}{|c|}{ Groups } \\
\hline & $\begin{array}{c}\text { M. oleifera }+ \text { Vaccine }+ \\
\text { Challenge } \\
\text { (g) }\end{array}$ & $\begin{array}{c}\text { M. oleifera }+ \text { No Vaccine } \\
+ \\
\text { Challenge } \\
(\mathrm{g})\end{array}$ & $\begin{array}{c}\text { Control Feed + Vaccine } \\
+ \text { Challenge } \\
\text { (g) }\end{array}$ & $\begin{array}{c}\text { Control Feed }+ \\
\text { NoVaccine }+ \text { No } \\
\text { Challenge } \\
\text { (g) }\end{array}$ \\
\hline 35 & $2.36 \mathrm{a} \pm 0.07$ & $2.28 \mathrm{a} \pm 0.07$ & $2.39 \mathrm{a} \pm 0.07$ & $2.37 \mathrm{a} \pm 0.07$ \\
\hline 38 & $2.32 \mathrm{a} \pm 0.07$ & $2.29 \mathrm{a} \pm 0.07$ & $2.34 \mathrm{a} \pm 0.07$ & $2.34 \mathrm{a} \pm 0.07$ \\
\hline 42 & $2.47 \mathrm{a} \pm 0.07$ & $2.44 \mathrm{a} \pm 0.07$ & $2.22 \mathrm{a} \pm 0.07$ & $2.49 a \pm 0.07$ \\
\hline 49 & $2.32 \mathrm{a} \pm 0.07$ & $2.33 \mathrm{a} \pm 0.07$ & $2.39 \mathrm{a} \pm 0.07$ & $2.34 \mathrm{a} \pm 0.07$ \\
\hline
\end{tabular}

All values are expressed as Means \pm SEM, values with different superscript a,b within rows differ significantly at $p<0.05$

Table 9: Change in some oxidative stress biomarkers for a unit loading of vvIBDV in broilers fed with Moringa oleifera supplemented diet and inoculated with vvIBDV.

\begin{tabular}{|c|c|c|c|c|}
\hline \multicolumn{5}{|c|}{ A35/D49 } \\
\hline Parameter & Estimates & Std. Error & Chi.sq & $P$ value \\
\hline Intercept & -36.22 & 11.38 & 10.14 & 0.0015 \\
\hline MDA & 6.82 & 1.98 & 11.85 & 0.0006 \\
\hline \multicolumn{5}{|c|}{ A38/D49 } \\
\hline Intercept & -16.50 & 9.36 & 3.10 & 0.078 \\
\hline GPx & 0.56 & 0.28 & 4.04 & 0.0445 \\
\hline \multicolumn{5}{|c|}{ B35/D49 } \\
\hline Intercept & -9.00 & 9.2 & 0.96 & 0.33 \\
\hline MDA & 3.64 & 1.83 & 3.94 & 0.0473 \\
\hline \multicolumn{5}{|c|}{ B38/D49 } \\
\hline Intercept & -12.75 & 9.54 & 1.79 & 0.18 \\
\hline MDA & 5.47 & 1.88 & 8.51 & 0.0035 \\
\hline \multicolumn{5}{|c|}{ C35/D49 } \\
\hline Intercept & -18.52 & 10.19 & 3.30 & 0.0692 \\
\hline CAT & -0.54 & 0.26 & 4.16 & 0.0414 \\
\hline MDA & 9.05 & 2.06 & 19.28 & 0.0001 \\
\hline GPx & 0.60 & 0.29 & 4.32 & 0.0376 \\
\hline \multicolumn{5}{|c|}{ C38/D49 } \\
\hline Intercept & -10.14 & 9.37 & 1.17 & 0.2794 \\
\hline CAT & -0.66 & 0.26 & 6.35 & 0.0117 \\
\hline
\end{tabular}




\begin{tabular}{ccccc}
\hline MDA & 5.17 & 1.87 & 7.60 & 0.0058 \\
GPx & 0.73 & 0.29 & 6.49 & 0.0109 \\
\hline Intercept & -7.00 & $\mathbf{C 4 2 / D 4 9}$ & 0.61 & 0.4344 \\
CAT & -0.64 & 8.97 & 6.21 & 0.0127 \\
GPx & 0.97 & 0.26 & 9.65 & 0.0019 \\
\hline Intercept & 0.31 & & 0.0467 \\
MDA & -19.26 & $\mathbf{C 4 9 / D 4 9}$ & 3.96 & 0.0068 \\
\hline $\mathrm{R}^{2}=0.1797(17.97 \%)$ & 5.05 & 9.68 & 7.34 & \\
\end{tabular}

Table 10: Effect likelihood ratio test for some oxidative stress biomarkers in broilers fed Moringa oleifera supplemented feed and inoculated with vvIBDV

\begin{tabular}{lcc}
\hline Parameter & Chi Square & P value \\
\hline Catalase & 27.88 & 0.0223 \\
Malondialdehyde & 89.11 & 0.0001 \\
Superoxidase dismutase & 14.04 & 0.5225 \\
Glutathione peroxidase & 16.66 & 0.3394 \\
\hline
\end{tabular}

The result of the effect likelihood ratio test showed the $\mathrm{R}^{2}$ is equal to 0.01797 , and $\mathrm{CAT}\left(\chi^{2}=27.88, \mathrm{P}=0.0223\right)$ and MDA $\left(\chi^{2}=89.11 ; \mathrm{P}=0.0001\right)$ concentration were significantly increased when compared to other oxidative biomarkers (Table 10).

\section{DISCUSSION}

In this study, the increase in the concentration of CAT and GPx at the peak of viremia (3 days post infection) in the broilers of group A, which was not observed in the broilers of the control group and that of group $\mathrm{C}$ (that were equally challenged with IBDV but not fed with MOL supplemented diet), could be attributed the excellent antioxidant capacity of MOL as reported by several authors (Siddhuraju and Becker 2003; Sreelatha and Padma 2009; Khalafalla et al., 2010; Balami et al., 2016). Based on stoichiometric studies, every disease was shown to have the capacity to cause oxidative stress in the host system through the production of free radicals (Niki 1996). Catalase and glutathione peroxidase have been reported as best-known defence systems (Valko et al., 2007), that is involved in the scavenging of free radicals that results from oxidative stress. Though, the effect of MOL supplemented diet on biomarkers of oxidative stress in broilers during infection has not been reported, Ertekin et al. (2016) reported a significant decrease in the concentration of CAT and SOD during IBD infection.

The significant increase observed in the concentration of MDA in broilers of group A when compared to those in the control group is as a result of lipid peroxidation. The level of lipid peroxidation and the concentration of the MDA in the blood is usually used as a biomarker of damage caused by free radicals caused by Reactive oxygen species (ROS) (Kuun and Borchert 2002; Sehirli et al., 2008; Yousef et al., 2009; Ding et al., 2011). One of the clinical signs of IBD infection is pyrexia (Abdu 2000). During the period of IBD infection, the infected bird would want to maintain an optimal temperature by increasing evaporative cooling, which in turn increases their metabolism and energy consumption (Gomez et al., 2002). This process is usually complicated by inappetence which that is usually associated with IBD infection. This increase need for energy is met by the metabolism of lipids from the stored fats, thereby degrading it causing peroxidation. Moringa oleifera leaf have been reported to have excellent antioxidant properties by several authors (Siddhuraju and Becker 2003; Sreelatha and Padma 2009; Khalafalla et al., 2010; Balami et al., 2016). This could be the reason observed in the significant increase in the concentration of MDA observed in the broilers of group A.

It was observed that three of the four oxidative stress biomarkers (CAT, GPx and MDA) evaluated in the present study were expressed significantly for every one unit increase in IBD viral load in broilers that were not fed with MOL supplemented diet. This implies that IBDV causes more oxidative stress in broilers as was reported by Ertekin et al. (2016). It was further affirmed the antioxidant capability of MOL especially during IBD infection. This is shown in the fewer number of the oxidative stress biomarkers expressed in broilers that were fed with MOL supplemented diet and challenged with IBDV. This also implied that for every one unit of IBD viral load in broilers, the antioxidants contained in MOL (Sreelatha and Padma 2009; Khalafalla et al., 2010; Balami et al., 2016) has the potential of scavenging the free radicals released due to IBD virus. The IBD virus was able to cause $17.97 \%$ change on the oxidative stress biomarkers. Similarly, this implies that, the antioxidants present in the MOL confers about $82.03 \%$ of the ameliorating effect (Fugile, 2005; Moyo et al., 2011) of the IBD virus by scavenging the free radical due to oxidative stress.

The effect of CAT and MDA were significantly expressed during the experimental challenge with the IBD virus in all the groups. This shows the importance of CAT and MDA during infection with IBDV. The concentration of MDA has been reported to significantly increase during infection with IBDV in broilers fed with Soybean Isoflavones supplemented diet (Azzam et al., 2019). Catalase have also been reported as one of the best-known defence systems that scavenges ROS (Valko et al., 2007) and CAT equally plays a role in the 
protection of the cell against lipid peroxidation (Yang et al., 2010).

\section{Conclusion}

Moringa oleifera leaf supplementation in the feed of broilers is shown to potentiate the antioxidant activities of CAT, GPX and MDA during infection with infectious bursal disease virus.

\section{Conflict of Interest}

The authors declare that they have no conflict of interest.

\section{Author's Contribution}

BAG, APA, WAM and AT did the experimental design. BAG wrote the manuscript. BAG and ESJ did the laboratory work. NJJ, AGS and GJJ proof read the manuscript. Statistical analysis was done by LA and MM. All authors have read and approved the final manuscript.

\section{REFERENCES}

Abdu, P.A. (1986). Infectious bursal disease immunization failures in chicken in Nigeria. Tropical Animal Health and Production, 18:123-125.

Ames, B.N., Shigenaga, M.K. and Hagen, T.M. (1993). Oxidants, antioxidants and the degenerative disease of aging. Proceeding of National Academy of Sciences. USA 90:7915-7922.

Anjorin, T.B., Ikokoh, P. and Okolo, S. (2010). Mineral composition of Moringa leaves, pods and seeds from two regions in Abuja, Nigeria. International Journal of Agriculture and Biology, 12: 431 - 434.

Aregheore, E.M. (2002). Intake and digestibility of Moringa oleifera batiki grass mixtures by growing goats. Small Ruminant Research, 46(1), 23-28. DOI: 10.1016/S0921-4488(02)00178-5

Aricibasi, M., Jung, A., Heller, E.D and Rautenschlein, S. (2010). Differences in genetic background influence the induction of innate and acquired immune responses in chickens depending on the on the virulence of the infecting Infectious Bursal Disease Virus (IBDV) strain. Veterinary Immonology and Immunopathology, 135(1-2): 7992. DOI: $10.1016 /$ j.vetimm.2009.11.005

Association of Official Analytical Chemists (AOAC) (1990). Official Methods of Analysis, Association of Official Analytical Chemists, Washington, D.C., USA. 15th Edition, pp. 807-928.

Azzam, M.M., Jiang, S., Chen, J., Lin, X., Gou, Z., Fan, Q., Wang, Y., Li, L. and Jiang, Z. (2019). Effect of soybean isoflavones on growth performance, immune function and viral protein 5 mRNA expression in broiler chickens challenged with infectious bursal disease virus. Animals, 9(247) 112.

Balami, A.G., Abdu, P.A., Wakawa, A.M and Aluwong, T. (2016). Evaluating the nutritional and therapeutic values of Moringa oleifera leaf supplementation in poultry feeds. Sahel Journal of Veterinary Science, 15(2) $113-120$.

Bukar, A.U. and Oyeyi, T.I. (2010). Antimicrobial profile of Moringa oleifera Lam. Extracts against some food- borne microorganisms, Bayero Journal of Pure and Applied Sciences, 3(1): 43-48. DOI: 10.4314/bajopas.v3i1.58706

Draper, H.H. and Hadley, M. (1990). Melondialdehyde determination as index of lipid peroxidation. Methods in Enzymology; 186:421-431. DOI: 10.1016/0076-6879(90)86135-I

Ertekin, A., Yildirim, B.A., Yildirim, S., Yildirim, F. and Tütüncü, M. (2016). Investigation of the lipid peroxidation, antioxidant enzymes, antioxidant vitamins, oxidation product of nitric oxide and some biochemical parameters in chicken with infectious bursal disease (IBD). Europ. Poultry Science., 80; 1-9. DOI: 10.1399/eps.2016.164

Fahey, J.W. (2005). Moringa oleifera: a review of the medical evidence for its nutritional, therapeutic, and prophylactic properties. Part1. Trees for Life Journal, 1(5). DOI: 10.1201/9781420039078.ch12

Falowo, A.B., Muchenje, V., Hugo, A., Aiyegoro, O.A. and Fayemi, P.O. (2017). Antioxidant activities of Moringa oleifera L. and Bidens pilosa L. leaf extracts and their effects on oxidative stability of ground raw beef during refrigeration storage. CyTA - Journal of Food, 15:2, 249-256, DOI: 10.1080/19476337.2016.1243587

Gomez, E., Dugue, P., Diaz, E., Facal, N., Antolin, I., Hidalgo, C. and Diez, C. (2002). Effects of acetoacetate and D-bete-hydroxybutyrate on bovine invitro embryo development in serum free medium. Theriogenology, 57(5):1551-1562. DOI: 10.1016/s009391x(02)00660-x

Jahn, S.A.A. (1984). Effectiveness of traditional flocculants as primary coagulants and coagulant aids for treatment of tropical raw water with more than a thousand-fold fluctuation in turbidity, Water Supply, 6: 8-10.

Khalafalla, M.M., Abdellatef, E., Dafalla, H.M., Nassrallah, A.A. and Aboul-Enein, K.M., Lightfoot, D.A. and El-Shemy, H.A. (2010). Active principle from Moringa oleifera Lam Leaves effective against two leukemias and a hepatocarcinoma. African Journal of Biotechnology. 9, 8467-8471. DOI: 10.5897/AJB10.996

Kunn, H. and Borchert, A. (2002). Regulation of enzymatic lipid peroxidation: The interplay of peroxidizing and peroxide reducing enzymes. Free Radical Biology and Medicine, 33: 154-172. DOI: 10.1016/s0891-5849(02)00855-9

Lu, T., Piao, X.L., Zheng, Q., Wang, D., Piao, X.S. and Kim, S.W. (2010). Protective effects of forsythia suspense extract against oxidative stress induced by diquate in rats. Food and Chemical Toxicology, 48:764-770. DOI: $10.1016 /$ j.fct.2009.12.018

Makkar, H.P.S. and Becker, K. (1999). Plant toxins and detoxification methods to improve feed quality of tropical seeds - review. Asian-Australian Journal of Animal Science, 12: 467-480. https://doi.org/10.5713/ajas

McDonald, P, Edwards, RA, Greenhalgh, J.F.O., Morgan, C.A. (1995). Animal nutrition. 4th Edn., John Wiley and sons, United State, pp: 607. 
Min, B.R., Nam, K.C., Cordray, J. and Ahn, D.U. (2008). Factors affecting oxidative stability of pork, beef, and chicken meat. Animal Industry Report: AS 654, ASL R2257. DOI: https://doi.org/10.31274/a ns air-180814-1046

Moyo, B., Masika, P.J., Hugo, A. and Muchenje, V. (2011). Nutritional characterization of Moringa (Moringa oleifera) Lam.) leaves. African Journal of Biotechnology. 10: 12925-12933.

Niki, E. (1996). Free radical- induced oxidative damage and nutritional oxidants. Proceedings of 2 nd W.H.O. Symposium on Health Issues for 21st Century, pp. 105-108.

Okeudo, N., Okoli, I.C. and Igwe, G.O.F. (2003). Haematological characteristics of ducks (Carina moschata) of South Eastern Nigeria. Tropicultura, 21: 61-65.

Okoye, J.O.A. (1983). The effect of late infectious bursal disease on the severity of naturally occurring Eimeria necatrix infection in chickens. Bulletin of Animal Health and Production in Africa, 31: 263267.

Olugbemi, T.S., Mutayoba, S.K and Lekule, F.P. (2010). Evaluation of Moringa oleifera leaf meal inclusion in cassava chip-based diets fed to laying birds. Livestock Research for Rural Development, 22 (6): 118. http://www.lrrd.org/lrrd22/6/olug22118.htm

Onu, P.N. and Aniebo, A.O. (2011). Influence of Moringa oleifera leaf meal on the performance and blood chemistry of starter broilers. International Journal of Food, Agriculture and Veterinary Sciences, 1 (1): 38-44.

Peterhans, E., Grob, M., Burge, T. and Zanoni, R. (1987). Virus-induced formation of reactive oxygen intermediates in phagocytic cells. Free Radical Research Communications, 3(1-5): 39-46. DOI: $10.3109 / 10715768709069768$

Ramachandran, C., Peter, K.V. and Gopalakrishnan, P.K. (1980). Drumstick (Moringa oleifera): a multipurpose Indian vegetable. Economic Botany, 34: 276-283. DOI 10.1007/BF02858648

Ray, G. and Husain, S.A. (2002). Oxidants, antioxidants and carcinogenesis. Indian Journal of Experimental Biology, 40 (11): 1213-1232.

Rehman, Z.U., Meng C., Umar, S., Munir, M. and Ding, C. (2016). Interaction of infectious bursal disease virus with the immune system of poultry. World's Poultry Science Journal, 72(4): 805-820. DOI: https://doi.org/10.1017/S0043933916000775

Reshi, M.L., Su, Y.C. and Hong, J.R. (2014). RNA viruses: ROS-mediated cell death. International Journal of Cell Biology, 1-16. DOI: 10.1155/2014/467452

Sandhu, S.K. and Kaur, G. (2002). Alterations in oxidative stress scavenger system in aging rat brain and lymphocytes. Biogerontology 3:161-173. DOI: 10.1023/a:1015643107449
Sehirli, O., Tozan, A., Omurtag, G.Z., Cetinel, S., Contuk, G., Gedik, N. and Sener, G. (2008). Protective effect of resveratrol against naphthalene-induced oxidative stress in mice. Ecotoxicology and Environmental Safety, 71:301-308. DOI: 10.1016/j.ecoenv.2007.08.023

Siddhuraju, P. and Becker, K. (2003). Antioxidant properties of various solvent extracts of total phenolic constituents from three different agroclimatic origins of drumstick tree (Moringa oleifera Lam.) leaves. Journal of Agriculture and Food Chemistry, 51, 2144-2155. https://doi.org/10.1021 /jf020444+

Sofowora, A. (1993). Medicinal Plants and Traditional Medicine in Africa; John Wiley and Sons, Ltd, Ife, Nigeria, Pp. 55-201.

Sreelatha, S. and Padma, P.R. (2009). Antioxidant activity and total phenolic content of Moringa oleifera leaves in two stages of maturity. Plant Food for Human Nutrition, 64, 303-311. DOI: 10.1007/s11130-009-0141-0

Valko, M., Leibfritz, D., Moncol, J., Cronin, M.T.D., Mazur, M. and Telser, J. (2007). Free radicals and antioxidants in normal physiological functions and human disease. International Journal of Biochemistry and Cell Biology, 39(1): 44-84. DOI: 10.1016/j.biocel.2006.07.001

Vyas, S., Kachhwaha, S. and Kothari, S.L. (2015). Comparative analysis of phenolic contents and total antioxidant capacity of Moringa oleifera Lam. Pharmacognosy Journal, 7(1): 44-51. DOI: $10.5530 / \mathrm{pj} .2015 .7 .5$

Wright, R.J., Lee, K.S., Hyacinth, H.I., Hibbert, J.M., Marvin, E.R., Wheatley, A.O and Asemota, H.N (2017). An investigation of the antioxidant capacity in extracts from Moringa oleifera plants grown in Jamaica. Plants, 6(4) 1-8. DOI: $10.3390 /$ plants6040048

Yang, L., Tan, G., Fu, Y., Feng J. and Zhang, M. (2010). Effect of acute heat stress and subsequent stress removal on function of hepatic mitochondrial respiration, ROS production and lipid peroxidation on broiler chickens. Comparative Biochemistry and Physiology. 151 (2): 204-208. DOI: 10.1016/j.cbpc.2009.10.010

Yavuz, T., Delibao, N., YâldÂrÂ̂m, B., Altuntao, I., CandÂr, O., Cora, A., Karahan, N., Âbrioim, E. and Kutsal, A. (2004). Vascular wall damage in rats induced by methidathion and ameliorating effect of vitamin $\mathrm{E}$ and C. Archives of Toxicology, 78: 655-659. DOI: 10.1007/s00204-004-0593-9

Yousef, M.I., Saad, A.A and El-Shennawy, L.K. (2009). Protective effect of grape seed anthocyanidin extract against oxidative stress induced by cisplatin in rats. Food and Chemical Toxicology; 46:11761183 . 